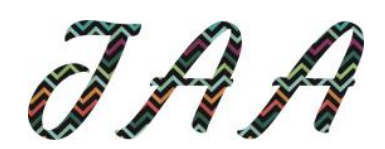

Vol. 6, No. 1, Oktober 2021

\title{
PENGARUH CASH HOLDING DAN FINANCIAL LEVERAGE TERHADAP PERATAAN LABA (INCOME SMOOTHING) DENGAN GOOD CORPORATE GOVERNANCE SEBAGAI VARIABEL MODERATING
}

\author{
Rahma Sari \\ Fakultas Ekonomi dan Bisnis, Universitas Trisakti \\ rahmasari547@yahoo.com \\ Deni Darmawati \\ Fakultas Ekonomi dan Bisnis, Universitas Trisakti \\ deni_darmawati@trisakti.ac.id
}

Article History:

Received: 27 Agustus 2021

Revised: 8 September 2021

Accepted: 13 September 2021

DOI: $10.29303 /$ jaa.v6i1.113

\begin{abstract}
Abstrak: Tujuan dari penelitian ini adalah untuk menguji pengaruh cash holding dan financiallleverage terhadap perataan laba (income smoothing) dengan goodlcorporatelgovernancelsebagai variabel moderating. Penelitian ini menggunakan perusahaan manufaktur yang terdaftarldi Bursa Efek Indonesia (BEI) tahun 2017-2019 sebagai sampel. Sampel penelitian ini berjumlah 174 perusahaan yang dipilih dengan metode purpossive sampling, dengan periode pengamatan 3 tahun. Metode yang digunakan untuk menganalisis hubungan antar variabel adalah metode regresi logistik. Berdasarkan hasil penelitian dapat diperoleh simpulan bahwa cash holding tidaklberpengaruh terhadap perataan laba (income smoothing), financial leverage berpengaruh terhadap perataan laba (income smoothing), good corporate governance tidak mampu memperlemah pengaruh cash holding terhadap perataan laba (income smoothing), dan good corporate governance mampu memperlemah pengaruh financial leverage terhadap perataan laba (income smoothing).
\end{abstract}

Kata kunci : Perataan Laba, Cash Holding, Financial Leverage, Good Corporate Governance

\section{Latar Belakang}

\section{PENDAHULUAN}

Laporan Keuangan merupakan gambaran terpenting bagi investor untuk menilai baik buruknya kinerja perusahaan. Tujuan pembuatan laporan keuangan oleh perusahaan adalah sebagai sarana informasi melalui media laporan keuangan yang dapat memberikan manfaat bagi pengunanya dalam pengambilan keputusan. Salah satu informasi yang sangat penting dalam pengambilan keputusan adalah informasi mengenai 
laba yang terdapat dalam laporan laba rugi perusahaan. Praktik perataan laba masih menjadi perdebatan berbagai pihak. Oleh sebagian pihak praktik perataan laba dianggap sebagai tindakan yang merugikan bagi pengguna laporan keuangan karena tidak menggambarkan secara wajar kondisi dan posisi keuangan perusahaan. Namun di sisi lain praktik peratan laba dinilai sebagai tindakan yang wajar karena tidak melanggar standar akuntansi meskipun dapat mengurangi keandalan laporan keuangan (Zuhriyah \& Wahidahwati, 2015).

Perataan laba (incomesmoothing) merupakan tindakan yang sengaja dilakukan untuk mengurangi fluktuasi laba dalam melaporkan kinerja perusahaan agar terlihat stabil dan sehat dimata investor (Pratiwi \& Damayanthi, 2017). Perataan laba (income smoothing) tidak akan terjadi jika laba yang dihasilkan sesuai dengan yang diharapkan. Konsep perataan laba (income smoothing) dilatarbelakangi oleh teori keagenan dalam teori keagenaan menyatakan bahwa manjemen merupakan pihak utama yang memegang peranan penting dan merupakan pihak yang mengetahui informasi penting tentang perusahaan dibandingkan pemilik atau pemegang saham. Sehingga pihak manajemen sering berada pada posisi dan situasi yang sangat mungkin menguntungkan dirinya sendiri atau perusahaan, karena manajemen dapat memanipulasi laba dalam laporan keuangan (Sari \& Oktavia, 2019). Tindakan perataan laba (income smoothing) tidak terlepas dari faktor-faktor yang mempengaruhinya, dalam penelitian ini salah satu faktor yang mempengaruhi perataan laba (income smoothing) antaralain cash holding, financiallleverage dan good corporatelgovernance.

Cash holding adalah kas yang ada di perusahaan dan berguna untuk melakukan berbagai aktivitas yang akan dilakukan oleh perusahaan. Cash holding memiliki hubungan yang signifikan dan searah dengan perataan laba (income smoothing), semakin tinggi kepemilikan kas atau kas dalam perusahaan maka perataan laba (income smoothing) akan semakin tinggi (Natalie \& Astika, 2016). Hal ini dikarenakan informasi yang terdapat dalam laporan keuangan mengenai kas di perusahaa memungkinkan investor untuk menilai kinerja manajemen dari kemampuannya mempertahankan peningkatan yang stabil pada kas di perusahaan. Karena peningkatan kas yang stabil di perusahaan membuat kinerja manajemen terlihat baik di mata investor, salah satu tindakan yang dilakukan manajemen adalah dengan melakukan perataan laba. Dengan adanya kas yang stabil di perusahaan menujukkan bahwa perusahaan memiliki tingkat risiko yang rendah, karena perusahaan dianggap mampu membayar kewajibannya. Adanya latar belakang tersebut membuat manjemen termotivasi untuk melakukan perataan laba melalui kas yang tersedia di perusahaan (Nirmanggi \& Muslih, 2020). Dalam penelitian yang dilakukan oleh (Dewi \& Latrini, 2016) menyatakan bahwa cash holding berpengaruh positif terhadap income smoothing. Berbeda hasil dengan penelitian yang dilakukan oleh (Dalimunthe \& Prananti, 2019) menyatakan bahwa cash holding tidak 


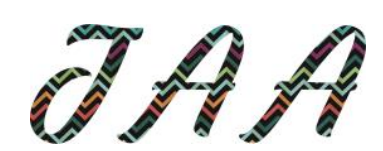

Vol. 6, No. 1, Oktober 2021

berpengaruh terhadap income smoothing.

Financial leverage menunjukkan proporsi utang yang digunakan untuk membiayai investasinya. Perusahaan yang memiliki tingkat leverage yang tinggi dapat dikatakan memiliki risiko yang lebih tinggi karena perusahaan akan membutuhkan lebih banyak asset untuk membayar kewajibannya (Jessica \& Dewi, 2019). Semakin besar hutang yang ditanggung perusahaan, maka secara tidak langsung risiko yang ditanggung oleh pemilik modal juga akan semakin besar. Hal ini menyulitkan perusahaan untuk mencari pihak yang ingin berinvestasi atau pihak yang ingin meminjamkan dana kepada perusahaan. Kondisi ini memunculkan keinginan manajemen untuk melakukan praktik perataan laba (Dalimunthe \& Prananti, 2019). Hal ini dikarenakan, tingkat hutang yang rendah menunjukkan perusahaan dapat menjalankan operasi bisnisnya tanpa harus bergantung pada pinjaman sehingga, menurunnya pengawasan yang dilakukan oleh kreditor dan meningkatkan kepercayaan investor untuk berinvestasi di perusahaan karena, investasi lebih aman di perusahaan yang memilki tingkat hutang yang rendah (Santioso, dkk 2019). Dalam penelitian yang dilakukan oleh (Sari \& Rudy, 2020) menyatakan bahwa financial leverage berpengaruh positif terhadap income smoothing. Berbeda hasil dengan penelitian yang dilakukan oleh (Wulandari \& Situmorang, 2020) menyatakan bahwa financial leverage tidak berpengaruh terhadap tindakan perataan laba.

Upaya untuk mengurangi perataan laba (income smoothing) dengan menerapkan good corporate governance di perusahaan. Good corporate governance dianggap sebagai solusi yang baik bagi perusahaan karena dapat menjadi langkah yang baik untuk mencegah kecurangan yang mungkin dilakukan oleh manajemen untuk menguntungkan diri sendiri. Salah satu kecurangan yang dilakukan oleh manajemen adalah dengan melakukan perataan laba di perusahaan dimana manajemen memanipulasi laba perusahaan agar sesuai dengan yang diharapkan (Teguh \& Hatane, 2017).

Penelitian ini mengintegrasikan beberapa faktor yang mempengaruhi perataan laba (income smoothing) yang telah dilakukan peneliti sebelumnya dan menggunakan variabel good corporate governance sebagai variabel moderating karena dengan menjalankan good corporate governance yang baik diharapkan mampu meminimalisir tindakan perataan laba (income smoothing). Penelitian ini bermaksud untuk menguji pengaruh cash holding dan financialleverage terhadap perataan laba (income smoothing). Dalam penelitian ini good corporate governance digunakan sebagai variabel moderating yang dapat memperlemah pengaruh cash holding dan financialleverage terhadap perataan laba (income smoothing).

Hasil penelitian ini berhasil menemukan penelitian yang dilakukan oleh (Dalimunthe \& Prananthi, 2019) yang menyatakan bahwa cash holding tidak berpengaruh terhadap perataan laba. Selanjutnya hasil 
penelitian ini berhasil menemukan penelitian yang dilakukan oleh (Sari \& Rudy, 2020) yang menyatakan bahwa financial leverage berpengaruh terhadap perataan laba. Selanjutnya penelitian ini berhasil menemukan penelitian yang dilakukan oleh (Juniarta \& Sujana, 2015) dan (Ernawati \& Suartana, 2018) yang menyatakan bahwa good corporate governance tidak mampu memperlemah pengaruh cash holding terhadap perataan laba. Selanjutnya penelitian ini berhasil menemukan penelitian yang dilakukan oleh (Pande \& Suryanawa, 2017) yang menyatakan bahwa good corporate governance mampu memperlemah pengaruh financial leverage terhadap perataan laba. Pembahasan dilanjutkan dengan reviu literatur dan hipotesis, kemudian diuraikan metode penelitian. Pembahasan selanjutnya dalam makalah ini adalah hasil analisis dan diskusi, kemudian ditutup dengan kesimpulan, keterbatasan, dan implikasi penelitian.

\section{REVIU LITERATUR DAN HIPOTESIS}

\section{Teori Keagenan (Agency Theory)}

Teori keagenan menggambarkan hubungan kontraktual antara agen dan principal. Dalam hubungan kontraktual principal atau pemegang saham menunjuk agen atau orang dari luar perusahaan untuk melakukan suatu jasa atas nama principal dan memberikan wewenang kepada agen untuk mengambil keputusan yang dapat menguntungkan bagi principal atau pemegang saham. Dalam hubungan kontraktual ini agen dapat memilih pilihan yang menguntungkan dirinya atau pilihan untuk memenuhi keinginan principal atau pemegang saham (Jensen \& Meckling, 1976).

(Eisenhardt, 1989) mengemukakan bahwa teori keagenan menggunakan asumsi dasar sifat manusia, yaitu mementingkan diri sendiri (self-interest), mememiliki batas daya pemikiran sehinggga tidak berpikir panjang untuk masa mendatang (bounded rationality) dan selalu selalu menghindari risiko (risk averse).

Hubungan antara teori keagenan dan perataan laba (income smoothing) adalah asumsi sifat dasar manusia bahwa manajer sebagai manusia akan bertindak oportunis, yaitu mengutamakan kepentingan pribadinya. Asumsi bahwa manusia pada umumnya egois menyebabkan agen mencoba memanfaatkan informasi asimetris yang tersedia untuk memanipulasi laporan keuangan agar sesuai dengan keinginannya. Tindakan agen tersebut dapat dilakukan dengan melakukan tindakan perataan laba agar laba yang dihasilkan sesuai dengan yang diharapkan (Apriani \& Wirawati, 2018).

\section{Manajemen Laba}

Menurut Scott, (2015) manajemen laba adalah kebijakan akuntansi pilihan manajer, atau tindakan nyata yang dilakukan oleh manajer sehingga mempengaruhi laba dalam rangka mencapai beberapa tujuan laba yang akan dilaporkan. Manajemen laba dapat didefinisikan sebagai 


\section{DA}

Vol. 6, No. 1, Oktober 2021

perilaku manajer dalam mengelola laba dengan metode tertentu. Manajemen laba bertujuan untuk menambah atau mengurangi laba yang dilaporkan, dan manajer bertanggungjawab untuk meningkatkan atau menurunkan profitabilitas ekonomi jangka panjang. Pola manajemen laba adalah: Taking a Bath, Income Minimization, Income Maximization dan Income Smoothing.

\section{Perataan Laba (Income Smoothing)}

Menurut (Pratiwi \& Damayanthi, 2017) perataan laba (income smoothing) adalah suatu metode yang sengaja digunakan untuk mengurangi fluktuasi laba dalam melaporkan hasil kinerja perusahaan agar terlihat stabil dan sehat. (Eckel, 1981) mengklasifikasikan income smoothing menjadi dua jenis yaitu real smoothing dan artificial smoothing. Menurut (Sarwinda \& Afriyenti, 2015) menyatakan bahwa alasan perataan laba adalah sebagai teknik untuk mengurangi keuntungan dan menambah biaya pada tahun berjalan sehingga pajak yang terutang pada perusahaan menjadi kecil. Selain itu, perataan laba ditujukan untuk peningkatan citra perusahaan di mata investor. Perataan laba juga ditujukan sebagai jembatan antara manjemen perusahaan dengan karyawannya. Perataan laba dapat menstabilkan adanya fluktuasi laba, sehingga dengan melakukan perataan laba manajemen dapat menghindari tuntutan kenaikan upah yang dituntut oleh karyawan ketika perusahaan mengalami penurunan laba yang diperoleh.

\section{Cash Holding}

Cash holding adalah kas yang tesedia di perusahaan yang berguna untuk menjalankan berbagai kegiatan operasional perusahaan. Berdasarkan The General Theory of Employment, Interest \& Money Keynes dalam Sarwinda \& Afriyenti 2015 menjelaskan bahwa ada tiga alasan atau motif kepemilikan uang tunai, yaitu motif transaksi, motif berjaga-jaga, dan motif spekulasi. Motif transaksi yaitu bahwa uang tunai digunakan untuk membayar barang dan jasa/transaksi harian. Motif berjaga-jaga yaitu bahwa uang tunai digunakan untuk investasi (misalnya, dalam bentuk saham/obligasi) karena investasi dianggap aman karena jarang kehilangan nilainya. Sedangkan motif spekulasi yaitu bahwa investor mengharapkan tingkat pengembalian maksimum dari investasi mereka.

Dalam penelitian ini cash holding diukur dengan cara kas ditambah setara kas dibagi dengan jumlah asset perusahaan. Adanya informasi laporan keuangan mengenai kas di perusahaan, memungkinkan investor untuk menilai kinerja manajer dari kemampuannya menjaga agar peningkatan kas di perusahaan tetap stabil (Revinsia dkk, 2019). Karena peningkatan kas yang stabil di perusahaan membuat kinerja manajemen terlihat baik di mata investor, salah satu tindakkan yang dilakukan manajemen adalah dengan perataan laba. Memiliki kas yang stabil dalam perusahaan menunjukkan bahwa perusahaan memiliki tingkat risiko yang rendah, karena perusahaan dianggap mampu membayar kewajibannya. 
Adanya latar belakang tersebut membuat manajemen termotivasi untuk melakukan perataan laba melalui kas yang tersedia di perusahaan (Nirmanggi \& Muslih, 2020).

\section{Financial Leverage}

Financial leverage menunjukkan proporsi utang yang digunakan untuk membiayai investasinya. Perusahaan yang memiliki tingkat leverage yang lebih tinggi dapat dikatakan memiliki risiko yang lebih tinggi karena perusahaan akan membutuhkan lebih banyak asset untuk membayar kewajibannya (Jessica \& Dewi, 2019). Dalam penelitian ini financial leverage diukur melalui Debt to Asset Ratio (DAR) karena debt to asset ratio menggambarkan kemampuan modal perusahaan untuk menjamin hutangnya dan menunjukkan proporsi beban perusahaan yang dibiayai oleh pemegang saham dan dibiayai oleh pinjaman, semakin besar hutang yang ditanggung perusahaan, maka secara tidak langsung risiko yang ditanggung oleh pemilik modal juga akan semakin besar. Hal ini menyulitkan perusahaan untuk mencari pihak yang ingin berinvestasi atau pihak yang ingin meminjamkan dana kepada perusahaan. Kondisi ini memunculkan keinginan manajemen untuk melakukan praktik perataan laba (Dalimunthe \& Prananti, 2019).

\section{Good Corporate Governance}

Forum for Corporate Governance Indonesia (FCGI), (2015) mendefinisikan corporate governance sebagai seperangkat peraturan yang mengatur hubungan antara pemegang saham, pengurus (pengelola), pihak kreditur, pemerintah, karyawan, serta para pemegang kepentingan internal dan eksternal lainnya yang berkaitan dengan hak-hak dan kewajiban mereka atau dengan kata lain suatu sistem yang mengatur dan mengendalikan perusahaan. Good corporate governance memberikan jaminan kepada para pemegang saham bahwa dana yang diinvestasikan dikelola dengan baik dan agen bekerja sesuai dengan fungsi, tanggungjawab dan untuk kepentingan perusahaan (Hamdani, 2016).

Peraturan Menteri Badan Usaha Milik Negara (BUMN) Nomor Per01/MBU/2011 tentang Penerapan Tata Kelola yang Baik pada BUMN sebagaimana diubah dengan Peraturan Menteri BUMN Per-09/MBU/2012, pada Pasal 1 Per-01/MBU/2011 diberikan pengertian good corporate governance berbunyi sebagai berikut "Tata Kelola Perusahaan yang Baik (Good Corporate Governance), yang selanjutnya disebut GCG adalah prinsip- prinsip yang mendasari suatu proses dan mekanisme pengelolaan perusahaan berlandaskan peraturan perundang-undangan dan etika berusaha". Kemudian pada Pasal 3 Per-01/MBU/2011 memberikan penjelasan menggenai prinsip-prinsip GCG sebagai berikut:

Transparansi (transparency), yaitu keterbukaan dalam melaksanakan proses pengambilan keputusan dan keterbukaan dalam mengunggkapkan inforrmasi material dan relevan mengenai perusahaan.

1. Akuntabilitas (accountability), yaitu kejelasan fungsi, 


\section{DA}

Vol. 6, No. 1, Oktober 2021

pelaksanaan dan pertanggungjawaban Organ sehingga pengelolaan perusahaan terlaksana secara efektif.

2. Pertanggungjawaban (responsibility), yaitu kesesuaian di dalam pengelolaan perusahaan terhadap peraturan perundangundangan dan prinsip-prinsip korporasi yang sehat.

3. Kemandirian (independency), yaitu keadaan di mana perusahaan dikelola secara profesional tanpa benturan kepentingan dan pengaruh/tekanan dari pihak manapun yang tidak sesuai dengan peraturan perundang- undangan dan prinsip-prinsip korporasi yang sehat.

4. Kewajaran (fairness), yaitu keadilan dan kesetaraan di dalam memenuhi hak- hak Pemangku Kepentingan (stakeholders) yang timbul berdasarkan perjanjian peraturan perundanganundangan.

Penerapan prinsip good corporate governance secara konsisten dapat meminimalkan tindakan oportunistik manajer dan menjadi penghambat kegiatan rekayasa kinerja perusahaan yang mengakibatkan laporan keuangan tidak mencerminkan nilai perusahaan yang sebenarnya. Semakin baik penerapan good corporate governance dapat menekan perusahaan untuk melakukan perataan laba, begitu pula sebaliknya. Baik tidaknya good corporate governance dapat dilihat melalui salah satunya dimensi keterbukkaan (transparansi) (Pande \& Suryanawa, 2017).

\section{Kerangka Pemikiran}

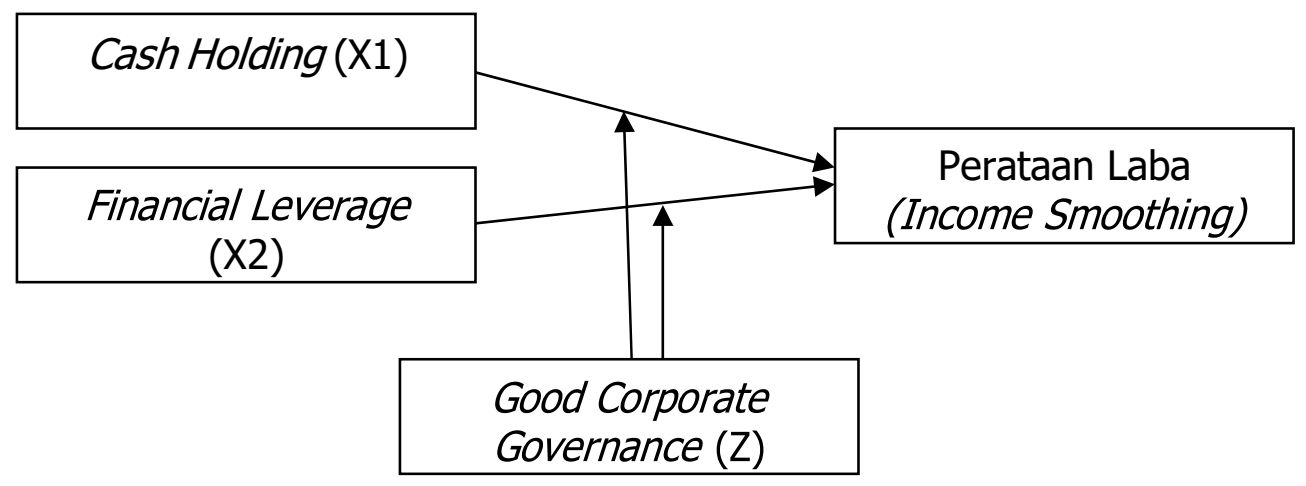

Gambar 2.1 Kerangka Pemikiran

\section{Hipotesis Penelitian}

\section{Pengaruh Cash Holding terhadap Perataan Laba (Income} Smoothing)

Cash holding adalah kas dalam perusahaan yang berguna untuk menjalankan berbagai kegiatan operasional perusahaan. Cash holding memiliki hubungan yang signifikan dan searah dengan perataan laba (income smoothing), semakin tinggi kepemilikan kas atau kas dalam 
perusahaan maka perataan laba (income smoothing) semakin tinggi (Natalie \& Astika, 2016). Hal ini dikarenakan informasi yang terdapat dalam laporan keuangan mengenai kas di perusahaan memungkinkan investor untuk menilai kinerja manajemen dari kemampuannya mempertahankan peningkatan yang stabil pada kas di perusahaan. Karena peningkatan kas yang stabil di perusahaan membuat kinerja manajemen terlihat baik di mata investor, salah satu tindakkan yang dilakukan manajemen adalah dengan perataan laba. Memiliki kas yang stabil dalam perusahaan menunjukkan bahwa perusahaan memiliki tingkat risiko yang rendah, karena perusahaan dianggap mampu membayar kewajibannya. Adanya latar belakang tersebut membuat manajemen akan termotivasi untuk melakukan perataan laba melalui kas yang tersedia di perusahaan (Nirmanggi \& Muslih, 2020). Karena jika perusahaan memiliki kas yang terlalu banyak (excess cash holding), maka perusahaan dapat kehilangan kesempatan untuk mendapatkan keuntungan yang lebih besar karena kas yang ada di perusahaan hanya disimpan dan tidak digunakan untuk melakukan investasi yang lebih menguntungkan. Namun jika perusahaan memiliki kas yang sedikit maka dapat mempengaruhi likuiditas perusahaan. Oleh karena itu perusahaan perlu menjaga agar kas di perusahaan tetap stabil (Dewi \& Latrini, 2016). Oleh karena itu, manajemen akan termotivasi untuk melakukan perataan laba melalui kas yang tersedia di perusahaan sehingga terlihat stabil di mata investor. Berdasarkan penjelasan diatas, maka dapat disimpulkan hipotesis sebagai berikut:

\section{H1: Cash Holding berpengaruh positif terhadap Perataan Laba (Income Smoothing)}

Pengaruh Financial Leverage terhadap Perataan Laba (Income

\section{Smoothing)}

Financial leverage menunjukkan proporsi utang yang digunakan untuk membiayai investasinya. Peningkatan hutang yang diikuti dengan laba yang stabil berarti perusahaan dianggap baik dalam mengelola hutangnya (Ditiya \& Sunarto, 2019). Perusahaan tidak selalu bisa membiayai investasinya dengan modal sendiri sehingga membutuhkan pinjaman dari pihak luar. Pinjaman dari luar akan menambahkan utang perusahaan juga akan meningkatkan risiko perusahaan, namun sekaligus akan meningkatkan tingkat pengembalian yang diharapkan. Untuk mendapatkan pinjaman, perusahaan harus meyakinkan kreditur akan kemampuannya untuk menggembalikan pinjaman, salah satu caranya adalah dengan melakukan income smoothing karena jika laba yang diperoleh relatif stabil antar periode, kreditur merasa yakin bahwa perusahaan mampu memenuhi kewajibannya untuk membayar melunasi utangnya dan menghindari pelanggaran perjanjian utang. Hutang dapat meningkatkan praktik income smoothing ketika entitas ingin menghindari kemungkinan pelanggaran perjanjian hutang dan untuk meningkatkan posisi tawar menawar perusahaan selama negosiasi hutang (Juniarta \& 


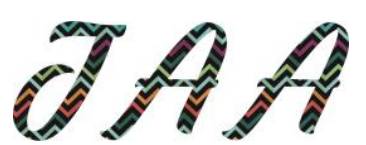

Vol. 6, No. 1, Oktober 2021

Sujana, 2015). Menurut (Dalimunthe \& Prananti, 2019) menyatakan bahwa hutang yang besar mengakibatkan peningkatan risiko, sehingga semakin besar leverage maka risiko yang ditanggung oleh pemilik modal juga akan meningkat. semakin besar hutang yang ditanggung perusahaan, maka secara tidak langsung risiko ditanggung oleh pemilik modal juga akan semakin besar. Hal ini menyulitkan perusahaan untuk mencari pihak yang ingin berinvestasi atau pihak yang ingin meminjamkan dananya kepada perusahaan. Kondisi ini menimbulkan keinginan manajemen untuk melakukan praktik perataan laba. Berdasarkan penjelasan diatas, maka dapat disimpulkan hipotesis sebagai berikut:

H2: Financial Leverage berpengaruh positif terhadap Perataan Laba (Income Smoothiing)

Good Corporate Governance memoderasi Pengaruh Cash Holding terhadap Perataan Laba (Income Smoothing)

Cash holding memiliki hubungan yang signifikan dan searah dengan perataan laba (income smoothing), semakin tinggi kepemilikan kas atau kas yang ada dalam perusahaan maka perataan laba (income smoothing) akan semakin tinggi (Natalie \& Astika, 2016). Adanya informasi yang terdapat dalam laporan keuangan mengenai kas di perusahaan membuat investor dapat menilai kinerja manajemen dari kemampuannya menjaga kenaikan kas di perusahaan agar tetap stabil. Adanya peningkatan kas yang stabil dalam perusahaan membuat kinerja manajemen terlihat baik dimata investor, sehingga salah satu tindakkan yang dilakukan manajemen adalah dengan melakukan perataan laba melalui kas yang tersedia di perusahaan (Nirmanggi \& Muslih, 2020). Good corporate governance diharapkan mampu meminimalkan tindakan perataan laba melalui pemantauan kinerja agen. Good corporate governance memberikan jaminan kepada para pemegang saham bahwa dana yang di investasikannya dikelola dengan baik dan agen bekerja sesuai dengan fungsi, tanggungjawab dan untuk kepentingan perusahaan (Hamdani, 2016). Berdasarkan penjelasan diatas, maka dapat disimpulkan hipotesis sebagai berikut:

H3: Good Corporate Governance memperlemah Pengaruh Cash Holding terhadap Perataan Laba (Income Smoothing)

Good Corporate Governance memoderasi Pengaruh Financial Leverage terhadap Perataan Laba (Income Smoothing)

Financial leverage menunjukkan proporsi utang yang digunakan untuk membiayai investasinya. Perusahaan yang memiliki tingkat leverage yang tinggi dapat dikatakan memiliki risiko yang lebih tinggi karena perusahaan akan membutuhkan lebih banyak asset untuk membayar kewajibannya (Jessica \& Dewi, 2019). Semakin besar hutang yang ditanggung perusahaan, maka secara tidak langsung risiko yang ditanggung oleh pemilik modal juga akan semakin besar. Hal ini menyulitkan perusahaan untuk mencari pihak yang ingin berinvestasi atau 
pihak yang ingin meminjamkan dana kepada perusahaan. Kondisi ini memunculkan keinginan manajemen untuk melakukan praktik perataan laba (Dalimunthe \& Prananti, 2019).

Penerapan prinsip good corporate governance secara konsisten akan meminimalkan tindakan oportunistik manajer dan menjadi penghambat kegiatan rekayasa kinerja perusahaan yang mengakibatkan laporan keuangan tidak mencerminkan nilai perusahaan yang sebenarnya. Semakin baik penerapan good corporate governance dapat menekan perusahaan melakukan perataan laba, begitu pula sebaliknya. Baik tidaknya good corporate governance dapat dilihat dari dimensi keterbukaan (transparansi) (Pande \& Suryanawa, 2017). Dengan demikian, corporate governance dapat mencegah perusahaan yang memiliki financial leverage tinggi untuk melakukan perataan laba (Thoharo \& Andayani, 2018). Berdasarkan penjelasan di atas, maka dapat disimpulkan hipotesis sebagai berikut:

H4: Good Corporate Governance memperlemah Pengaruh Financial Leverage terhadap Perataan Laba (Income Smoothing)

\section{METODE PENELITIAN}

\section{Variabel dan Pengukuran Variabel Dependen}

Variabel dependen dalam penelitian ini adalah perataan laba (income smoothing). Perataan laba (income smoothing) merupakan tindakan yang sengaja dilakukan untuk mengurangi fluktuasi laba dalam melaporkan hasil kinerja perusahaan agar terlihat stabil dan sehat (Pratiwi \& Damayanthi, 2017). (Eckel, 1981) menyatakan rumus yang digunakan dalam mengukur income smoothing adalah sebagai berikut:

$$
\text { Indeks Eckel : } \frac{\operatorname{cv} \Delta \mathrm{I}}{\mathrm{CV} \Delta \mathrm{S}}
$$

Keterangan:

$\Delta \mathrm{S} \quad$ : Perubahan penjualan dalam satu periode

$\Delta \mathrm{I} \quad$ : Perubahan penghasilan bersih/ laba dalam satu periode

CV : Koefisien variasi dari variabel, yaitu standar deviasi dengan nilai yang diharapkan

$\mathrm{CV} \Delta I$ : Koefisien variasi untuk perubahan laba

$\mathrm{CV} \Delta S$ : Koefisien variasi untuk perubahan penjualan Dimana $\mathrm{CV} \Delta \mathrm{I}$ atau $\mathrm{CV} \Delta \mathrm{S}$ dirumuskan dengan: Keterangan:

$$
\sqrt{\frac{\sum(\Delta x-\Delta \bar{x})^{2}}{n-1}}: \Delta \bar{x}
$$


Vol. 6, No. 1, Oktober 2021

$\Delta x$ : Perubahan laba bersih (I) atau penjualan (S) antara tahun $\mathrm{n}$ dengan tahun $\mathrm{n}-1$

$\Delta \bar{x}$ : Rata-rata perubahan laba bersih (I) atau penjualan (S) antara tahun dengan tahun $\mathrm{n}-1$

$n$ : Jumlah tahun yang diteliti

Jika CV $\Delta \mathrm{I}>\mathrm{CV} \Delta \mathrm{S}$, maka perusahaan tersebut tidak tergolong perusahaan yang melakukan praktik perataan laba dan jika $\mathrm{CV} \Delta \mathrm{I}<\mathrm{CV}$ $\Delta \mathrm{S}$,maka perusahaan tersebut tergolong perusahaan yang melakukan praktik perataan laba.

\section{Variabel Independen}

Variabel independen dalam penelitian ini adalah cash holding dan financial leverage.

1. Cash Holding

$$
\text { Cash Holding: } \frac{\text { Kas + Setara Kas }}{\text { Total Aset }}
$$

Cash holding diukur dengan membandingkan jumlah kas dan setara kas yang dimiliki perusahaan dengan jumlah asset perusahaan. Menurut (Tamara \& Tjundjung, 2019) cash holding dirumuskan sebagai berikut:

\section{Financial Leverage}

Debt to Asset Ratio (DAR) menggambarkan rasio yang digunakan untuk mengukur seberapa besar asset perusahaan dibiayai oleh utang atau seberapa besar utang perusahaan mempengaruhi pembiayaan asset dengan membandingkan antara total utang dengan total asset. Menurut (Sari \& Rudy, 2020) financial leverage dirumuskan sebagai berikut:

$$
\text { Financial Leverage: } \frac{\text { Total Utang }}{\text { Total Aset }}
$$

\section{Variabel Moderasi}

Variabel moderasi dalam penelitian ini adalah good corporate governance. Good corporate governance merupakan pedoman yang dimiliki oleh perusahaan yang akan dikelola oleh orang-orang yang memiliki keahlian dalam mencapai keuntungan untuk kepentingan perusahaan. Good corporate governance dalam penelitian ini diukur dengan menggunakan indikator Asean Corporate Governance Scorecard (ACGS) dengan bentuk check list untuk masing-masing perusahaan.

Dalam penelitian ini indikator yang digunkan adalah indikator pengungkapan dan transparansi serta indikator tanggungjawab dewan 
yang berkaitan erat dengan praktik manajemen laba. Hal ini sejalan dengan yang dilakukan oleh (Linawati, 2017). Jumlah indikator keseluruhan sebanyak 121 indikator. Pengungkapan good corporate governance dalam check list menggunakakan skor 1 untuk perusahaan yang mengungkapkan dan 0 jika tidak mengungkapkan. Kemudian skor tersebut dijumlahkan untuk mengetahui total pengungkapan good corporate governance perusahaan (Linawati, 2017).

\section{Prosedur Pengumpulan Data}

Populasi dalam penelitian ini adalah perusahaan manufaktur yang terdaftar di Bursa Efek Indonesia periode 2017-2019. Teknik pengambilan sampel dalam penelitian ini menggunakkan metode purposive sampling dengan menentukan sampel berdasarkan kriteria tertentu. Ada 173 perusahaan manufaktur yang terdaftar di Bursa Efek Indonesia periode 2017-2019. Berdasarkan kriteria yang telah ditentukan, didapat sebanyak 58 perusahaan manufaktur yang terdaftar di Bursa Efek Indonesia periode 2017-2019 dengan jumlah sampel sebanyak 174 perusahaan. Berikut ringkasan prosedur pemilihan sampel dalam penelitian ini:

\section{Tabel 1}

\section{Kriteria Pemilihan Sampel}

\begin{tabular}{clc}
\hline No & \multicolumn{1}{c}{ Kriteria } & Jumlah \\
\hline 1 & $\begin{array}{l}\text { Perusahaan manufaktur yang terdaftar di Burs Efek Indonesia (BEI) } \\
\text { periode 2017-2019 }\end{array}$ & 173 \\
2 & $\begin{array}{l}\text { Perusahaan yang baru listing serta tidak menyediakan laporan keuangan dan } \\
\text { tahunan di Bursa Efek Indonesia (BEI) periode 2017-2019 }\end{array}$ & $(43)$ \\
3 & Perusahaan manufaktur yang mengalami kerugian selama periode 2017-2019 & $(43)$ \\
4 & Perusahaan manufaktur yang tidak menggunakan mata uang rupiah dalam & $(27)$ \\
& laporan keuangan dan tahunan periode 2017-2019 & $(2)$ \\
5 & Outlier & $\mathbf{5 8}$ \\
\hline & Jumlah Perusahaan Manufaktur yang masuk kedalam kriteria & $\mathbf{1 7 4}$ \\
\hline
\end{tabular}

\section{Metode Analisis Data}

Metode analisis data dalam penelitian ini menggunakan analisis regresi logistik karena variabel dependen dalam penelitian ini diukur menggunakan dummy. Analisis regresi logistik digunakan untuk menguji pengaruh variabel independen yaitu cash holding dan financial leverage terhadap perataan laba (income smoothing) dengan good corporate governance sebagai variabel moderating. Model regresi logistik dalam penelitian ini adalah sebagai berikut:

$$
\operatorname{Ln} \frac{(I S)}{1-I S}=a+\beta 1 C H+\beta 2 D A R+\beta 3 C H * G C G+\beta D A R * G C G+e
$$




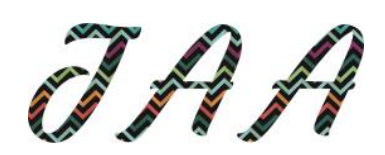

Vol. 6, No. 1, Oktober 2021

Keterangan:

$$
\begin{array}{ll}
\operatorname{Ln} \frac{(\mathrm{IS})}{1-\mathrm{IS}}= & \text { Dummy Variabel Dependen (Income Smoothing) } \\
& =\text { Nilai Konstanta } \\
\beta & =\text { Nilai Regresi } \\
\mathrm{CH} & =\text { Cash Holding } \\
\text { DAR } & =\text { Debt to Asset Ratio (Financial Leverage) } \\
\text { GCG } & =\text { Good Corporate Governance } \\
\mathrm{e} & =\text { error }
\end{array}
$$

\section{ANALISIS DATA DAN PEMBAHASAN}

\section{Statistik Deskriptif}

Data yang digunakan dalam penelitian ini merupakan data sekunder yang diperoleh dari website resmi BEI www.idx.co.id. Statistik deskriptif dalam penelitian ini dapat dilihat dalam tabel berikut:

Tabel 2 Statistik Deskriptif

\begin{tabular}{|c|c|c|c|c|c|}
\hline Variabel & $\mathbf{N}$ & Minimum & Maximum & Mean & Std.Deviation \\
\hline CH & 174 & 0,0008 & 0,6323 & 0,125123 & 0,1291931 \\
\hline DAR & 174 & 0,0369 & 0,7813 & 0,364497 & 0,1775346 \\
\hline GCG & 174 & 0,3306 & 0,7769 & 0,572811 & 0,0877177 \\
\hline
\end{tabular}

Varibel cash holding dengan nilai minimum sebesar 0.0008 dimiliki oleh PT. Wilmar Cahaya Indonesia Tbk (CEKA) tahun 2018, sedangkan nilai maximum sebesar 0,6323 dimiliki oleh PT Delta Djakarta Tbk (DLTA) tahun 2018 dan nilai mean sebesar 0,125123 dan standar deviasi sebesar 0,1291931. Hal ini menunjukkan bahwa rata- rata cash holding perusahan manufaktur di Indonesia adalah sebesar $12 \%$ dari total asset.

Variabel financial leverage yang diproksi oleh Debt to Asset Ratio (DAR) memiliki nilai minimum sebesar 0,0369 dimiliki oleh PT Ricky Putra Globalindo Tbk (RICY) tahun 2017, sedangkan nilai maximum sebesar 0,7813 dimiliki oleh PT Indal Alluminium Industry Tbk (INAI) tahun 2018 dan nilai mean sebesar 0,364497 dan standar deviasi sebesar 0,1775346. Hal ini menunjukkan bahwa rata-rata perusahaan manufaktur di Indonesia dalam mengelola assetnya tidak begitu bergantung pada hutang, mengingat nilai rata-rata financial leverage dibawah angka 1 (satu).

Variabel good corporate governance memiliki nilai minimum sebesar 0,3306 oleh PT Wilmar Cahaya Indonesia Tbk (CEKA) tahun 2017, sedangkan nilai maximum sebesar 0,7769 dimiliki oleh PT Kabelindo Murni Tbk (KBLM) tahun 2019 dan nilai mean sebesar 0,572811 dan standar deviasi sebesar 0,0877177. hal ini menunjukkan bahwa rata-rata perusahaan manufaktur di Indonesia memiliki tingkat pengungkapan good corporate governance yang cukup baik yaitu sebesar $57 \%$. 


\section{Frekuensi Perataan Laba}

\section{Tabel 3 Frekuensi Perataan Laba}

\begin{tabular}{|c|c|c|c|}
\hline Dummy & & Frequency & Percent \\
\hline 0 & Bukan Perusahaan Perataan Laba & 81 & 46,6 \\
\hline 1 & Perusahaan Perataan Laba & 93 & 53,4 \\
\hline & Total & 174 & 100,0 \\
\hline
\end{tabular}

Jumlah data yang digunakan adalah 174 sampel data, yang diperoleh dari sampel sebanyak 58 perusahaan dikalikan dengan periode penelitian 3 tahun, yaitu 2017-2019. Perusahaan yang tidak melakukan perataan laba sebanyak 81 perusahaan atau $(46,6 \%)$. Sedangkan perusahaan yang melakukan perataan laba sebanyak 93 perusahaan atau $(53,4 \%)$.

\section{Analisis Regresi Logistik}

Menilai Kelayakan Model Regresi (Goodness-of-fit-test)

Hosmer and Lemesshow's digunakan untuk menguji kelayakan sebuah model regresi.

\section{Tabel 4}

Hasil Uji Goodness-of-fit-test

\begin{tabular}{|l|r|r|lr|}
\hline Step & Chi-square & \multicolumn{1}{|c|}{ df } & \multicolumn{2}{|c|}{ Sig. } \\
\hline 1 & 6,824 & 8 & & 0,556 \\
\hline
\end{tabular}

Berdasarkan tabel 4 hasil uji goodness of-fit-test dapat diketahui bahwa nilai chi-square sebesar 6,824 dengan tingkat signifikan sebesar 0,556 >0,05. Berdasarkan kriteria dalam pengambilan keputusan, dapat disimpulkan bahwa model mampu memprediksi nilai pengamatan atau dapat dikatakan model dapat diterima karena cocok dengan data observasinya.

\section{Menilai Keseluruhan Model (Overall Model Fit)}

Uji overall modelfit adalah pengujian yang dilakukan untuk melihat apakah model keseluruhan fit atau tidak, diperlukan uji Log Likellihood Value (Nilai -2LL) yang membandingkan nilai -2LL di awal (Block Number $=0$ ) dengan Block Number $=1$. Berikut adalah hasil pengujian overall fit model: 


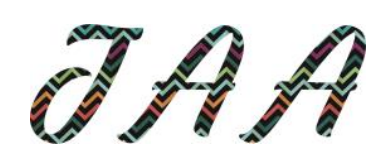

Vol. 6, No. 1, Oktober 2021

Tabel 5

Hasil Uji Overall Model Fit

\begin{tabular}{|l|c|r|c|}
\hline \multicolumn{1}{|c|}{ Iteration } & Model & -2Log Likelihood & Keputusan \\
\hline Block 0 & & 223,305 & \multirow{2}{*}{ Model Fit } \\
\cline { 1 - 3 } Block 1 & 1 & 222,605 & \\
\hline
\end{tabular}

Berdasarkan tabel 5 terlihat nilai -2 LL block 1 mengalami penurunan menjadi 222,605. Jika nilai -2LL awal > -2LL akhir maka dapat dikatakan model cocok dengan data.

\section{Uji Hipotesis}

\section{Uji Koefisien Determinasi (Nagelkerke R Square)}

Pada model regresi logistik, koefisien determinasi ditunjukkan dengan nilai Nagelkerke $R^{2}$ nya. Nilai Nagelkerke $R^{2}$ menunjukkan seberapa jauh kemampuan variabel independen dalam penelitian ini untuk mempengaruhi variabel dependennya.

Tabel 6

Hasil Uji Nagelkerke R Square

\begin{tabular}{|r|r|r|r|}
\hline Step & -2 Log Likelihood & $\begin{array}{c}\text { Cox \& Snell } \\
\text { R Square }\end{array}$ & Nagelkerke R Square \\
\hline 1 & 222,605 & 0,097 & 0,130 \\
\hline
\end{tabular}

Artinya kombinasi antara variabel independen mampu menjelaskan variabel -variabel dependen sebesar $13 \%$ sedangkan sisanya dipengaruhi faktor lain diluar penelitian ini.

\section{Omnibus test of Model Coefficient (Pengujian Simultan)}

Sebelum dilakukan pengujian hipotesis terlebih dahulu dilakukan uji seluruh model untuk melihat besarnya pengaruh variabel independen yang terdapat dalam model regresi terhadap variabel dependennya secara bersama-sama dari model regresi logistik yang digunakan. Berdasarkan tabel 7 dibawah menunjukan nilai Chi- square sebesar 17,782 dan sig $0,001<0,05$ sesuai dengan kriteria pengambilan keputusan, maka dapat disimpulkan bahwa variabel independen secara bersama- sama mampu mempengaruhi variabel dependen atau dengan kata lain model tersebut layak digunakan. 
Tabel 7

Hasil Uji Omnibus test of Model Coefficient

\begin{tabular}{|l|l|r|r|r|}
\hline & & Chi-square & \multicolumn{1}{c|}{ Df } & \multicolumn{1}{c|}{ Sig. } \\
\hline \multirow{3}{*}{ Step 1} & Step & 17,782 & 4 & 0,001 \\
\cline { 2 - 5 } & Block & 17,782 & 4 & 0,001 \\
\cline { 2 - 5 } & Model & 17,782 & 4 & 0,001 \\
\hline
\end{tabular}

\section{Uji Wald (Uji Individu)}

Uji wald bertujuan untuk melihat apakah variabel independen secara parsial memberikan pengaruh terhadap variabel dependen.

Tabel 8 Hasil Uji Wald

\begin{tabular}{|l|l|r|r|l|l|}
\hline & $\begin{array}{c}\text { Arah } \\
\text { Hasil }\end{array}$ & $\begin{array}{c}\text { Koefisien } \\
\text { (B) }\end{array}$ & $\begin{array}{c}\text { P-one } \\
\text { tailed }\end{array}$ & Keterangan & Keputusan \\
\hline Constant & & 0,512 & 0,135 & & \\
\hline $\mathrm{CH}$ & Negatif & $-10,219$ & 0,096 & Tidak berpengaruh & $\mathrm{H}_{1}$ Ditolak \\
\hline DAR & Positif & 4,905 & 0,026 & Berpengaruh & $\mathrm{H}_{2}$ Diterima \\
\hline CH*GCG & Positif & 22,075 & 0,053 & Tidak berpengaruh & $\mathrm{H}_{3}$ Ditolak \\
\hline DAR*GCG & Negatif & $-11,582$ & 0,003 & Berpengaruh & $\mathrm{H}_{4}$ Diterima \\
\hline
\end{tabular}

Berdasarkan tabel 8 maka persamaan regresi logistik yang diperoleh adalah sebagai berikut:

\section{$\mathrm{Y}=0,512-10,219 \mathrm{CH}+4,905 \mathrm{DAR}+22,075 \mathrm{CH} * \mathrm{GCG}-$ 11,582 DAR*GCG + e}

Berdasarkan hasil uji wald pada tabel 8 , nilai signifikan variabel cash holding terhadap perataan laba 0,096, lebih besar dar nilai signifikan sebesar 0,05 (0,096>0,05) dengan nilai koefisien -10,219 memiliki arah negatif. Dari hasil tersebut dapat dielaskan bahwa $\mathbf{H 1}$ ditolak yang berarti cash holding tidak berpengaruh terhadap perataan laba. Variabel financial leverage terhadap perataan laba sebesar 0,026 lebih kecil dari nilai signifikan sebesar $0,05(0,026<0,05)$ dengan nilai koefisien sebesar 4,905 yang arahnya positif. Dari hasil tersebut dapat dielaskan bahwa H2 diterima yang berarti financial leverage berpengaruh terhadap perataan laba. Variabel good corporate governance yang memoderasi pengaruh 


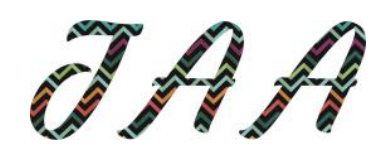

Vol. 6, No. 1, Oktober 2021

cash holding terhadap perataan laba memiliki nilai signfikansi sebesar 0,053 lebih besar dari 0,05 $(0,053>0.05)$ dengan nilai koefisien 22,075 yang arahnya positif. Dari hasil tersebut dapat dijelaskan bahwa H3 ditolak yang berarti good corporate governance tidak memoderasi pengaruh cash holding terhadap perataan laba. Sedangkan variabel good corporate governance yang memoderasi pengaruh financial leverage terhadap peraataan laba memiliki nilai signifikansi sebesar 0,003 lebih kecil dari 0,05 $(0,003<0,05)$ dengan nilai koefisien 11,582 memiliki arah negatif. Dari hasil tersebut dapat dijelaskan bahwa H4 diterima yag berarti good corporate governance mampu memperperlemah pengaruh financial leverage terhadap perataan laba.

\section{Pembahasan Hasil Penelitian}

\section{Cash Holding tidak berpengaruh terhadap Perataan Laba (Income Smoothing)}

Berdasarkan hasil penelitian tersebut menunjakkan H1 ditolak yang berarti cash holding tidak berpengaruh terhadap parataan laba. Analisis statistik deskriptif menunjukkan bahwa ratarata cash holding perusahaan manufaktur di Indonesia selama periode $2017-2019$ adalah $12 \%$ yang masih terlalu kecil untuk berpengaruh terhadap perataan laba. Hasil penelitian ini didukung penelitian yag dilaksanakan oleh (Dalimunthe \& Prananti, 2019) menemukan bahwa cash holding tidak berpengaruh terhadap peratan laba. Hal ini dikarenakan perusahan yang tidak mempunyai cash holding yag cukup untuk melaksanakan perataan laba, selain itu perusahaan di Indonesia masih sedikit aliran kas bebas, sehingga ketika perusahaan tidak mencukupi untuk membayar dividen atau mendanai investasi pada proyak-proyek perusahaan baru, maka tindakkan perusahaan selanjutnya adalah mengakumalasi kas (cash holding) atau bahkan melakukan pendanaan melalui hutang. (Tamara \& Tjundjung, 2019) menemukan bahwa adanya pengaruh perhatian publik yang hanya memperhatikan profit yang dihasilkan perusahaan, sehingga dengan adanya cash holding tidak memberikan tekanan kepada manajemen yag bisa mendorongnya untuk melaksanakan praktik perataan laba (income smoothing).

2. Financial Leverage berpengaruh positif terhadap Perataan Laba (Income Smoothing)

Berdasarkan hasil penelitian tersebut menunjukkan H2 diterima yang artinya financialleverage berpangaruh positif terhadap perataan laba (income smoothing). Hasil penelitian ini didukung penelitian yag dilaksanakan oleh (Sari \& Rudy, 2020) yang menemukan bahwa financial leverage berpengaruh terhadap perataan laba. Besar kecilnya tingkat leverage bisa mendorong 
manajemen agar melaksanakan tindakan perataan laba karena leverage menunjukkan proporsi utang yang digunakan untuk pembiayaan asset. Sehingga perusahaan yang mempunyai leverage yang tinggi, akan membuat pihak eksternal tidak mempercayai perusahaan, sehingga perusahaan harus dapat menyeimbangkan antara hutang dan keuntungan yang diterima. Manajemen melakukan perataan laba dengan tujuan untuk menunjukkan kepada kreditor bahwa perusahaan memiliki risiko yag kecil (Shabilla \& Nugroho, 2020). Tingkat hutang yang rendah menunjukkan bahwa perusahaan dapat menjalankan operasi bisnisnya tanpa harus bergantung pada pinjaman, sehingga mengakibatkan penurunan pengawasan oleh kreditur dan meningkatkan kepercayaan investor untuk berinvestasi di perusahaan, karena investasi lebih aman di perusahaan yang memiliki tingkat hutang yang rendah (Santioso, dkk 2019).

3. Good Corporate Governance tidak mampu memoderasi pengaruh Cash Holding terhadap Perataan Laba (Income Smoothing)

Berdasarkan hasil penelitian tersebut menunjukkan $\mathbf{H 3}$ ditolak yang berarti good corporate governance tidak mampu memoderasi pengaruh cash holding terhadap perataan laba (income smoothing). Hasil penelitian ini tidak sejalan dengan hipotesa awal yang menduga bahwa good corporate governance mampu memperlemah pengaruh cash holding terhadap perataan laba (income smoothing). (Juniarta \& Sujana, 2015) menemukan bahwa adanya goodcorporate governance yang diproksi oleh kepemilikan institusional merupakan pemilik yang lebih fokus pada keuntungan. Hal ini seringkali membuat manajemen melaksanakan perataan laba (income smoothing). (Ernawati \& Suartana, 2018) berpendapat bahwa kepemilikan institusional akan membuat manajer merasa terikat untuk memenuhi target laba bagi investor, sehingga akan cenderung melaksanakan tindakan manipulasi laba. Hal ini sejalan dengan hasil hipotesis satu yang menyatakan bahwa cash holding tidak berpengaruh terhadap perataan laba sehingga variabel interaksinya juga tidak mempunyai pengaruh terhadap perataan laba.

4. Good Corporate Governance mampu memoderas pengaruh Financial Leverage terhadap Perataan Laba (Income Smoothing)

Berdasarkan hasil penelitian tersebut menunjukkan H4 diterima yang berarti good corporate governance mampu memperlemah pengaruh financial leverage terhadap perataan laba (income smoothing). Hasil penelitian ini didukung penelitian yang dilakukan oleh (Pande \& Suryanawa, 2017) menemukan bahwa penerapan good corporate governance yang konsisten dapat 


\section{DAP}

Vol. 6, No. 1, Oktober 2021

meminimalkan tindakan perataan laba oleh manajemen dan menjadi penghambat aktivitas rekayasa kinerja yang menghasilkan laporan keuangan tidak mencerminkan nilai perusahaan yang sebenarnya. Selain itu, membantu memantau kinerja manajemen dengan baik agar perusahaan sesuai dengan kinerja yang diharapkan. (Hertika dkk, 2020) menyatakan bahwa tata kelola suatu entitas yang baik merupakan salah satu cara yang bisa dilaksanakan pemilik perusahaan untuk meminimalkan praktik perataan laba sehingga dapat dihasilkan laporan keuangan yang berkualitas baik (quality of financial reporting) dan dapat di pertanggungjawabkan.

\section{Simpulan}

\section{SIMPULAN, KETERBATASAN DAN IMPLIKASI}

Penelitian ini bertujuan untuk mengetahui pengaruh cash holding dan financial leverage terhadap perataan laba (income smoothing) dengan good corporate governance sebagai variabel moderating pada perusahaan manufaktur yang terdaftar di Bursa Efek Indonesia (BEI) periode 2017-2019. Sehingga bisa disimpulkan sebagai berikut, cash holding tidak berpengaruh terhadap perataan laba (income smoothing), Financial leverage berpengaruh terhadap perataan laba (income smoothing), Good corporategovernance tidak mampu memperlemah pengaruh cash holding terhadap perataan laba (income smoothing), Good corporate governance mampu memperlemah pengaruh financial leverage terhadap perataan laba (income smoothing).

\section{Keterbatasan}

Penelitian ini hanya menggunakan dua variabel independen yaitu cash holding dan financial leverage sehingga hasil yang diperoleh dari kedua variabel tersebut hanya dapat mepengaruhi praktik income smoothing sebesar $13 \%$ sedangkan sisanya dipengaruhi oleh variabel lain diluar penelitian ini. Selain itu, terdapat beberapa nilai ekstrim yang terdapat pada sampel penelitian dan dilakukan outlier data sehingga hasil dalam penelitian ini tidak mencerminkan nilai pada jumlah sampel yang sebenarnya.

\section{Implikasi}

Penelitian ini diharapkaan dapat menjelaskan teori sebelumnya yaitu teori agensi yang kemudian dapat dikembangkan mengenai teori keagenan yang berkaitan dengan perataan laba (income smoothing). Berdasarkan penelitiaan ini faktor yang mempengaruhi perataan laba adalah leverage, sehingga faktor tersebut dapat menjadi pertimbangan investor untuk melaksanakan investasi dengan harapan mendapatkan tingkat pengembalian investasi yang sesuai dan perusahaan harus mempertimbangkan faktor-faktor yang mempangaruhi perataan laba (income smoothing) terutama dari sisi leverage, sebab dalam 
penelitian ini variabel tersebut memiliki pengaruh terhadap perataan laba (income smoothing). Perusahaan harus memperhatikaan dalam pengelolaan hutang yang memiliki pengaruh terhadap perataan laba (income smoothing).

\section{DAFTAR PUSTAKA}

Dalimunthe, I. P., \& Prananti, W. (2019). PENGARUH CASH HOLDING, PROFITABILITAS, DAN FINANCIAL LEVERAGE TERHADAP INCOME SMOOTHING PADA PERUSAHAAN MANUFAKTUR. Diponegoro Journal of Accounting, Vol. 3 (1), 1-12. http://ejournals1.undip.ac.id/index.php/accounting\%0AVolume

Dewi, N. M. S. S., \& Latrini, M. Y. (2016). Pengaruh Cash Holding, Profitabilitas Dan Reputasi Auditor Pada Perataan Laba. E-Jurnal Akuntansi Universitas Udayana, 15(3), 2378-2408.

Ditiya, Y. D., \& Sunarto. (2019). Ukuran Perusahaan, Profitabilitsa, Financial Leverage, Boox-Tax Differences Dan Kepemilikan Publik Terhadap Perataan Laba (Studi Empiris pada Perusahaan Manufaktur yang Terdaftar di Bursa Efek Indonesia Periode 20142017). Dinamika Akuntansi, Keuangan Dan Perbankan, 8(1), 5163.

Eckel, N. (1981). Smoothing Hypothesis Revisited. Abacus, 17(1), 28-40.

Eisenhardt, K. M. (1989). Building Theory from Case Study Reaserch. The Academy of Menagement Review, 14(4).

Ernawati, L. K. Y., \& Suartana, I. W. (2018). Pengaruh Asimetri Informasi , Agency Cost, dan Kepemilikan Institusional Pada Income Smoothing. E-Jurnal Akuntansi Universitas Udayana, 24(1), 451480.

Forum for Corporate Governnace in Indonesia (FCGI). 2015. Peran Dewan Komisaris dan Komite Audit dalam Pelaksanaan Corporate Governance (Tata Kelola Perusahaan). Jakarta.

Ghozali, Imam. 2016. Aplikasi Analisis Multivariate Dengan Program IBM SPSS 23.

ISBN: 979.704.015.1. Edisi 8. Universitas Diponegoro.Hertika, D. P., Mawardi, M. C., \& Anwar, S. A. (2020). Pengaruh Penerapan Corporate Governance, Sektor Industri, Profitabilitas, dan Financial Leverage Terhadap Praktik Perataan Laba pada Perusahaan yang Terdaftar di BEI Tahun 2015- 2018. E-Jra, 09(05), 143-153.

Jensen, M., C., dan Meckling, W. (1976). "Theory of the firm: Managerial Behavior, Agency Cost and Ownership Structure". Journal of Finance Economic 3:305-360. Jessica, \& Dewi, S. P. (2019). FaktorFaktor Yang Mempengaruhi Income Smoothing Pada Perusahaan Manufaktur Di Bei. Jurnal Multiparadigma Akuntansi, 1(2), 425- 


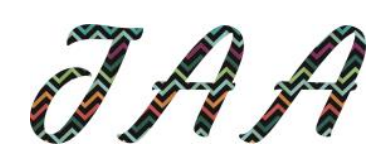

Vol. 6, No. 1, Oktober 2021

432.

Juniarta, I. W. A., \& Sujana, I. K. (2015). Pengaruh Financial Leverage Pada Income Smoothing Dengan Good Corporate Governance Sebagai Variabel Pemoderasi. E- Jurnal Akuntansi Universitas Udayana, 11(3), 921-939.

Kusmiyati, S. D., \& Hakim, M. Z. (2020). Pengaruh Ukuran Perusahaan, Profitabilitas, Cash Holding, Debt To Equity Ratio Dan Net Profit Margin Terhadap Perataan Laba (Studi Empiris Pada Perusahaan Manufaktur Sektor Industri Barang Konsumsi yang Terdaftar di Bursa Efek Indonesia Tahun 2014-2018) S. Komunikasi Ilmiah Akuntansi Dan Perpajakan, 13(1),58-72

http://dx.doi.org/10.22441/profita.2020.v13i1.005.

Linawati. (2017). Pengaruh Tingkat Hutang, Arus Kas Dan Akrual Terhadap Persistensi Laba Dengan Corporate Governance Sebagai Variabel Moderating (Studi Empiris pada Perusahaan yang Terdaftar di BEI Tahun 2011-2015). Jurnal Universitas Pamulang.

Natalie, N., \& Astika, I. B. P. (2016). Pengaruh Cash Holding, Bonus Plan, Reputasi Auditor, Profitabilitas, dan Leverage pada Income Smoothing, Bali: E-Jurnal Akuntansi Universitas Udayana Vol.15.2 Mei (2016): 943-972 ISSN: 2302-8556.

Nirmanggi, I. P., \& Muslih, M. (2020). Pengaruh Operating Profit Margin, Cash Holding, Bonus Plan, dan Income Tax terhadap Perataan Laba. 5 no 1, hal"25-44.

Rahmadani, F., Wijayanti, A., \& Fajri, R. N. (2020). Pengaruh Biaya Politik, Cash Holding, dan Kualitas Auditor terhadap Income Smoothing. Ekonomis: Journal of Economics and Business, 4(1), 113. https://doi.org/10.33087/ekonomis.v4i1.96.

Sari, I. P., \& Oktavia, F. (2019). Pengaruh Return On Equity, Risiko Keuangan, Ukuran Perusahaan dan Kepemilikan Manajerial terhadap Income Smoothing. Menara Ilmu, XIII(2), 77-84. https://jurnal.umsb.ac.id/index.php/menarailmu/article/view/11 92.

Sari, N. mustika, \& Rudy. (2020). Analisis Pengaruh Profitabilitas, Leverage dan Ukuran Perusahaan terhadap Income Smoothing. Buana Akuntansi, 5(1), 15-31.

Sarwinda, P., \& Afriyenti, M. (2015). Pengaruh Cash Holding , Political Cost, dan Nilai Perusahaan Terhadap Tindakan Perataan Laba ( Studi Empiris Pada Perusahaan Manufaktur Yang Terdaftar Di BEI 2009-2013 ). Seminar Nasional Ekonomi Manajemen Dan Akuntansi (SNEMA) Fakultas Ekonomi Universitas Negeri Padang, C, 517-529.

Scott, W. R. (2015). Financial Accounting Theory. 7 th edition. Canada Inc: Pearson Edu- cation. 
Shabila, A., \& Nugroho, W. S. (2020). Pengaruh Financial Leverage, Ukuran Perusahaan, Profitabilitas, dan Struktur Kepemilikan Terhadap Praktik Perataan Laba. Issue: $3^{\text {rd }}$ Prosiding Business and Economics ConferenceIn Utilizingof Modern Technology 2020.

Tamara, O., \& Tjundjung, H. (2019). Faktor-Faktor Yang Mempengaruhi Income Smoothing Pada Perusahaan Manufaktur. Jurnal Multiparadigma Akuntansi, 1(3), 655-665.

Thoharo, A., \& Andayani. (2018). Pengaruh Profitabilitas, Leverage, Dan Kebijakan Dividen Terhadap Income Smoothing, Dengan Komite Audit Sebagai Variabel Pemoderasi. Jurnal Ilmu dan Riset Akuntansi, 7(2), 1-24.

Udayana, E. A. U. (2017). E-Jurnal Akuntansi Universitas Udayana CORPORATE GOVERNANCE SEBAGAI VARIABEL PEMODERASI I Made Andika Pramana Pande 1 Fakultas Ekonomi dan Bisnis Universitas Udayana ( Unud ), Bali , Indonesia Fakultas Ekonomi dan Bisnis Universitas Udayana ( Unud ), Bali. 21, 1630-1659.

Wulandari, Z., \& Situmorang, I. R. (2020). Pengaruh Profitabilitas, Ukuran Perusahaan dan Financial Leverage Terhadap Perataan Laba ( Studi Pada Perusahaan Manufaktur yang Terdaftar di BEI Tahun 20142018 ). 2012, 30-43.

Zuhriya, S. \& Wahidahwati. (2015). Perataan Laba dan Faktor - Faktor yang Mempengaruhi Perusaan Manufaktur di BEI. Jurnal Ilmu Dan Riset Akuntansi, 4 No. 7(7), 1-22. 